\title{
PERANCANGAN SISTEM INFORMASI COMPLAINT MANAGEMENT DENGAN METODE RAD MENGGUNAKAN FRAMEWORK LARAVEL
}

\author{
Falaah Abdussalaam $^{*}$, Samdea Anggieta Saputra \\ ${ }^{1,2}$ Program Studi Manajemen Informatika, Politeknik Piksi Ganesha, Bandung, Indonesia \\ *Email: falaahabdussalaam@gmail.com
}

\begin{abstract}
This study aims to determine the complaint management system that is running in PT Andalan Teknologi Mandiri, to know the obstacles and how to overcome the constraints of complaint management system problems. From the results of research that has been obtained, it turns out that the main obstacle of complaint management system in PT Andalan Technology Mandiri is the handling of customer complaints have not recorded either manually any computerized. Where the data handling complaints is needed by the company to meet ISO 9001 company standards. method of designing information systems using UML modeling (Unified Modelling Language) then implemented using web-based programming language framework Laravel with integration MySQL database applications. Then the software development method used is RAD (Rapid Application Development). The suggestions provided are: 1) required system administrator to manage complaint management information system 2) application made can be developed from the side of notification using email and SMS gateway to facilitate customer, engineer, and administrator get progress ticket information made.
\end{abstract}

Keywords: Information system, Complaint management, Laravel framework, MySQL

\section{PENDAHULUAN}

\subsection{Latar Belakang}

Konsep manajemen komplain (complaint management) merupakan sebuah sarana yang dapat digunakan untuk membangun komunikasi dengan pengguna dan memperoleh umpan-balik tentang tingkat kepuasan pengguna terhadap pelayanan perusahaan. Komplain yang diajukan oleh pengguna kemudian akan ditindak-lanjuti dengan perbaikan atau klarifikasi dari pihak perusahaan guna mengurangi kekecewaan dan meningkatkan kepuasaan user/ pengguna. PT. Andalan Teknologi Mandiri merupakan perusahan kontraktor yang mempunyai tiga kelompok roda bisnis yang terdiri dari konstruksi sipil, instalasi mekanikal elektrikal dan teknologi informasi. Pada saat ini belum tersedia bentuk penanganankomplain yang menggunakan sistem informasi, hal ini menyebabkan perusahaan tidak dapat melakukan analisis terhadap kontrol kualitas produk dan jasa yang dikerjakan sertakurang efektifnya monitoring kinerja sub kontraktor di lapangan karena tidak tersedianya data history penanganan komplain dari pengguna, untuk memenuhi standar perusahaan ISO 9001terkait standar operasional pelayanan perusahaan terhadap user dan peningkatan kualitas kinerja, maka diperlukan pembangunan sistem informasi complaint management.

\subsection{Pokok Permasalahan}

Berdasarkan pengamatan penulis, permasalahan yang terjadi di PT Andalan Teknologi Mandiri, terkait dengan pengelolaan manajemen komplain, diantaranya:

a. Tidak adanya layanan interaksi antara perusahaan dengan pengguna untuk mempermudah proses komplain yang ter-manage.

b. Belum terlaksananya monitoring kualitas pekerjaan produk dan jasa yang dilakukan oleh staf lapangan PT. Andalan Teknologi Mandiri.

c. Tidak tersedianya data history penanganan komplain dari pengguna, untuk memenuhi standar perusahaan ISO 9001terkait standar operasional pelayanan perusahaan terhadap user.

\subsection{Tujuan Penelitian}

Tujuan Penelitian ini untuk menganalisis, merancang dan membangun Sistem Informasi Complaint Managementdi PT. Andalan Teknologi Mandiri berbasis web menggunakanFramework Laravel dandatabase MySQL sehinggapengelolaan complaintdapat diakses lebih mudah, cepat dan akurat serta memenuhi syarat perusahaan untuk mempunyai standar ISO 9001. 


\section{MATERI DAN METODE}

\section{1. Pendekatan Umum}

\subsubsection{Perancangan Sistem Informasi}

Menurut Satzinger, Jackson dan Burd (2010:5) mendefinisikan "Perancangan Sistem adalah kumpulan aktivitas yang menggambarkan secara rinci bagaimana sistem akan berjalan". Sedangkan menurut Mohamad Subhan (2012:109), "Perancangan adalah proses pengembangan spesifikasi baru berdasarkan rekomendasi hasil analisis sistem".

Menurut Bonita J. Campbel (1979) dalam Bambang Hartono (2013:10) mendefinisikan "Sistem sebagai himpunan bagian-bagian atau komponen yang saling berkaitan dan secara bersama sama berfungsi atau bergerak untuk mencapai suatu tujuan". Sedangkan menurut Tata Sutabri (2012:6), "Sistem adalah sekelompok unsur yang erat hubungannya satu dengan yang lain, yang berfungsi bersama sama untuk mencapai suatu tujuan tertentu".

Definisi informasi menurut McLeod yang dikutip oleh Yakub (2012:8) adalah "Data yang diolah menjadi bentuk yang lebih berguna dan lebih berarti bagi yang menerimanya". Sedangkan menurut Sutarman (2012:14), "Informasi adalah sekumpulan fakta (data) yang diorganisasikan dengan cara tertentu sehingga mempunyai arti bagi si penerima".

Dari definisi diatas dapat disimpulkan bahwa Perancangan Sistem Informasi merupakan suatu tahap kegiatan yang dilakukan oleh individu ataupun kelompok untuk membangun atau mengembangkan sebuah sistem yang mencakup pendefinisian dari kebutuhan - kebutuhan fungsional yang menggambarkan bagaimana suatu sistem dibangun dengan tujuan untuk memecahkan suatu permasalahan dan memenuhi kebutuhan implisit dan eksplisit dari pengguna.

\subsubsection{Complaint Management}

Komplain atau keluhan itu sebenarnya merupakan bagian dari bentuk "Komunikasi“. Sebuah informasi tentang ketidaksesuaian yang dirasakan pihak kedua yang menerima sebuah jasa atau produk. Oleh karena itu, Komplain atau keluhan itu sebenarnya dibutuhkan, karena complaint akan menghasilkan sebuah informasi. Entah informasi positif atau informasi negatif. Bahkan komplain itu merupakan sebuah komunikasi aktif yang bisa menjurus kedalam sebuah "interaksi“.

Sistem Manajemen Komplain harus didesain dan dilaksanakan untuk mengkoversi complainingcustomer menjadi satisfied customers. Dengan sistem manajemen komplain, keluhan dapat ditangani dengan lebih baik dan ini sekaligus menunjukkan pentingnya perhatian dan kepedulian organisasi kepada pelanggannya. Dengan sistem manajemen komplain pula, organisasi akan senantiasa mau mendengarkan pelanggannya, mau belajar dari kesalahan-kesalahannya dan terus-menerus mau memperbaiki dan meningkatkan mutu pelayanannya.Keberhasilan manajemen komplain dipengaruhi oleh:

a. Personal Factors yaitu faktor keahlian, rasa percaya diri, motivasi dan komitmen masing-masing personal pelayanan.

b. Leadership Factors yaitu faktor kualitas dorongan, bimbingan dan dukungan yang diberikan oleh atasan dan pimpinan tim.

c. Team Factors yaitu faktor kualitas dukungan dari seluruh anggota tim pelayanan.

d. System Factors yaitu faktor sistem kerja yang handal dan fasilitas yang memadai yang disediakan oleh organisasi pelayanan.

e. Contextual (Situational) Factors yaitu situasi dan kondisi lingkungan baik internal maupun eksternal.

\subsection{Pendekatan Khusus}

\section{a. Framework Laravel}

Laravel adalah sebuah framework PHP yang dirilis dibawah lisensi MIT, dibangun dengan konsep MVC (Model View Controller). Laravel adalah pengembangan website berbasis MVP yang ditulis dalam PHP yang dirancang untuk meningkatkan kualitas perangkat lunak dengan mengurangi biaya pengembangan awal dan biaya pemeliharaan, dan untuk meningkatkan pengalaman bekerja dengan aplikasi dengan menyediakan sintaks yang ekspresif, jelas dan menghemat waktu. Konsep MVC (Model View Controller) Laravel Framework disajikan pada Gambar 1. 


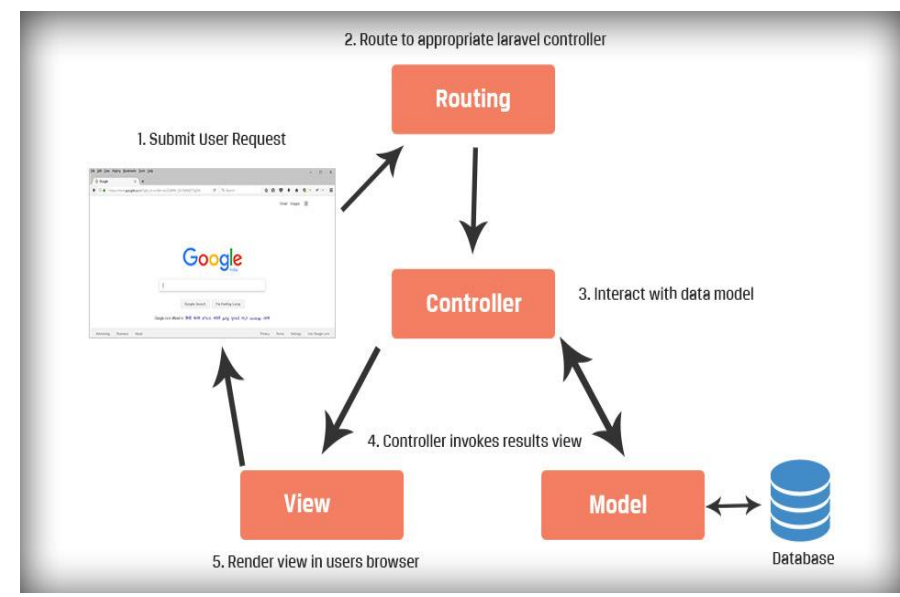

Gambar 1. Konsep MVC (Model View Controller) Laravel Framework

Beberapa fitur yang terdapat di Laravel:

1) Bundles, yaitu sebuah fitur dengan sistem pengemasan modular dan tersedia beragam di aplikasi.

2) Eloquent ORM, merupakan penerapan PHP lanjutan menyediakan metode internal dari pola "active record" yang mengatasi masalah pada hubungan objek database.

3) Application Logic, merupakan bagian dari aplikasi, menggunakan controller atau bagian route.

4) Reverse Routing, mendefinisikan relasi atau hubungan antara Link dan Route.

5) Restful controllers, memisahkan logika dalam melayani HTTP GET and POST.

6) Class Auto Loading, menyediakan loading otomatis untuk class PHP.

7) View Composer, adalah kode unit logikal yang dapat dieksekusi ketika view sedang loading.

8) IoC Container, memungkin obyek baru dihasilkan dengan pembalikan controller.

9) Migration, menyediakan sistem kontrol untuk skema database.

10) Unit testing, banyak tes untuk mendeteksi dan mencegah regresi.

11) Automatic Pagination, menyederhanakan tugas dari penerapan halaman

\section{b. Unified Modelling Language (UML)}

Unified Modelling Language (UML) menurut Nugroho (2010:6) merupakan "Bahasa pemodelan untuk sistem atau perangkat lunak yang berparadigma berorientasi objek, pemodelan (modelling) sesungguhnya digunakan untuk menyederhanakan permasalahan-permasalahan yang 2.3 Metode kompleks sedemikian rupa sehingga lebih mudah untuk dipelajari dan dipahami”.

Rapid Application Development (RAD) adalah sebuah model proses perkembangan software sekuensial linier yang menekankan siklus perkembangan yang sangat pendek. Model RAD ini merupakan sebuah adaptasi "kecepatan tinggi" dari model sekuensial linier dimana perkembangan cepat dicapai dengan menggunakan pendekatan konstruksi berbasis komponen. Proses pengembangan software tradisional dan rad disajikan pada Gambar 2.

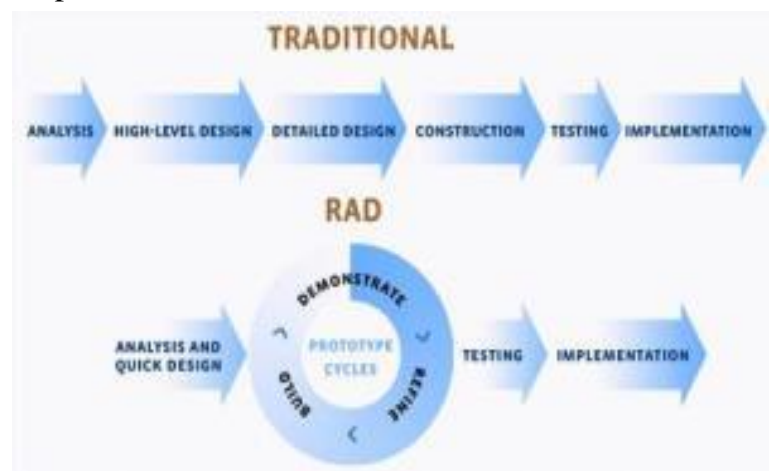

Gambar 2. Proses Pengembangan Software Tradisional dan RAD 
Pengembangan digunakan terutama pada aplikasi sistem konstruksi, pendekatan RAD melingkupi fase-fase sebagai berikut:

a. Bussines Modelling

Bussines modelling yaitu aliran informasi diantara fungsi-fungsi bisnis dimodelkan dengan suatu cara untuk menjawab pertanyaan-pertanyaan berikut:

1) Informasi apa yang mengendalikan proses bisnis?

2) Informasi apa yang akan dimunculkan pada sistem informasi yang dibuat?

3) Siapa yang memunculkanya?

4) Kemana informasi itu pergi?

5) Siapa yang memprosesnya?

b. Data Modelling

Data modelling yaitu aliran informasi yang didefinisikan sebagai bagian dari fase bussiness modelling disaring ke dalam serangkaian objek data yang dibutuhkan untuk menopang bisnis tersebut. Karakteristik (disebut atribut) masing-masing objek diidentifikasi dan hubungan antara objek-objek tersebut didefinisikan.

c. Proses Modelling

Proses modelling yaitu aliran informasi yang didefinisikan di dalam fase data modelling dan ditransformasikan untuk mencapai aliran informasi yang diperlukan bagi implementasi sebuah fungsi bisnis. Gambaran pemrosesan diciptakan untuk menambah, memodifikasi, menghapus, atau mendapatkan kembali sebuah objek data.

d. Application Generation

RAD mengasumsikan pemakaian teknik application generation (generasi keempat). Selain menciptakan perangkat lunak dengan menggunakan bahasa pemrograman generasi ketiga yang konvensional, RAD lebih banyak memproses kerja untuk memakai lagi komponen program yang ada (pada saat memungkinkan) atau menciptakan komponen yang bisa dipakai lagi (bila perlu). Pada semua kasus, alat-alat bantu otomatis dipakai untuk memfasilitasi konstruksi perangkat lunak.

e. Testing and Turnover

Karena proses RAD menekankan pada pemakaian kembali, banyak komponen program telah diuji. Hal ini mengurangi keseluruhan waktu pengujian. Tetapi komponen baru harus diuji dan semua interfaceharus dilatih secara penuh.

\section{HASIL DAN PEMBAHASAN}

\subsection{Analisis Sistem}

Analisis sistem informasi complaint managementdi PT Andalan Teknologi Mandiri, penulis uraikan sebagai berikut :

a. Dari hasil penelitian yang telah didapat, ternyata yang menjadi kendala utama sistem complaint management di PT Andalan Teknologi Mandiri adalah penangan keluhan customer belum tercatat baik secara manual maupun secara komputerisasi. Dimana data penangangan keluhan tersebut sangat diperlukan oleh perusahaan untuk memenuhi standar perusahaan ISO 9001.

b. Dari hasil analisis, diperlukan perancangan sistem informasi complaint managementyang dapat memenuhi kebutuhan dan harapan dari pengguna, dengan spesifikasi sistem informasi sebagai berikut:

\section{1) User management}

Program harus memenuhi kebutuhan pengolahan userdibagi atas 3 role yaitu user, administrator, dan engineer.

2) Ticket management

Ticket management yang diharapkan dapat menampung ticket keluhan yang dibuat dengan menampilkan status ticketOpen untuk status yang baru dibuat oleh user, status In Progress apabila engineer sedang melakukan penanganan keluhan, status Finished apabila engineer selesai melakukan perbaikan, dan status Closed apabila ticket keluhan sudah ditutup.

3) Report management

Sistem informasi dapat menampilkan history penanganan ticket dengan identitas engineer yang menangani keluhan. Kemudian data hasil report tersebut digunakan sebagai acuan perbaikan kinerja teknisi lapangan, dan sub-kontraktor atas pekerjaan yang dilakukan dan kualitas yang diimplementasikan di lapangan.

4) User Feedback 
Ketika ticket keluhan sudah ditutup atau mempunyai status Closed, maka user untuk mengisi tombol feedback berupa nilai kepuasan atas penangan keluhan yang dilakukan oleh engineer dan respon dari administator yang kemudian data feedback ini digunakan perusahaan untuk memenuhi standar ISO 9001 tentang manajemen mutu pelayanan operasional perusahaan.

5) BerbasisWeb

Bahasa pemrograman yang dapat digunakan untuk membangun sistem informasi complaint management adalah dengan bahasa pemrograman berbasis web untuk memudahkan pengaksesan sistem. Kali ini penulis menggunakan framework laravel untuk membuat sistem informasi complaint management di PT. Andalan Teknologi Mandiri

6) Internet Hosting

Agar sistem informasi yang dibuat dapat diakses oleh user dimana dan kapan saja maka web dapat disimpan di penyedia layanan hosting dan terdapat email notification untuk pemberitahuan tentang update progress penanganan ticket keluhan yang dibuat user oleh administrator dan engineer.

\subsection{Perancangan Sistem}

Perancangan sistem ini dibuat sebagai tahapan untuk mempersiapkan proses implementasi dan untuk memberikan gambaran umum tentang sistem yang dikembangkan kepada penggunanya. Adapun tujuan dari perancangan sistem yang diusulkan yaitu :

a. Membuat fitur input keluhan, bertujuan untuk menerima inputan berupa data lengkap keluhan pelanggan.

b. Membuat fitur pendataan informasi status keluhan, bertujuan untuk memberikan informasi proses penangan keluhan yang dibuat.

c. Membuat fitur manajemen user, berfungsi untuk pengelompokan user berdasarkan priviledge, diantaranya customer, engineer, atau admistrator.

d. Membuat fitur laporan, berfungsi membuat laporan dari keluhan yang telah dibuat oleh customer sebagai acuan perbaikan pelayanan perusahaan.

\subsubsection{Rancangan Fungsional}

a. Use Case Diagram

Dari analisis sistem yang penulis lakukan, maka use casesistem informasi complaintmanagementdapat digambarkan sebagai berikut:

1) Use Case Diagram Alur Administrator disajikan pada Gambar 3.

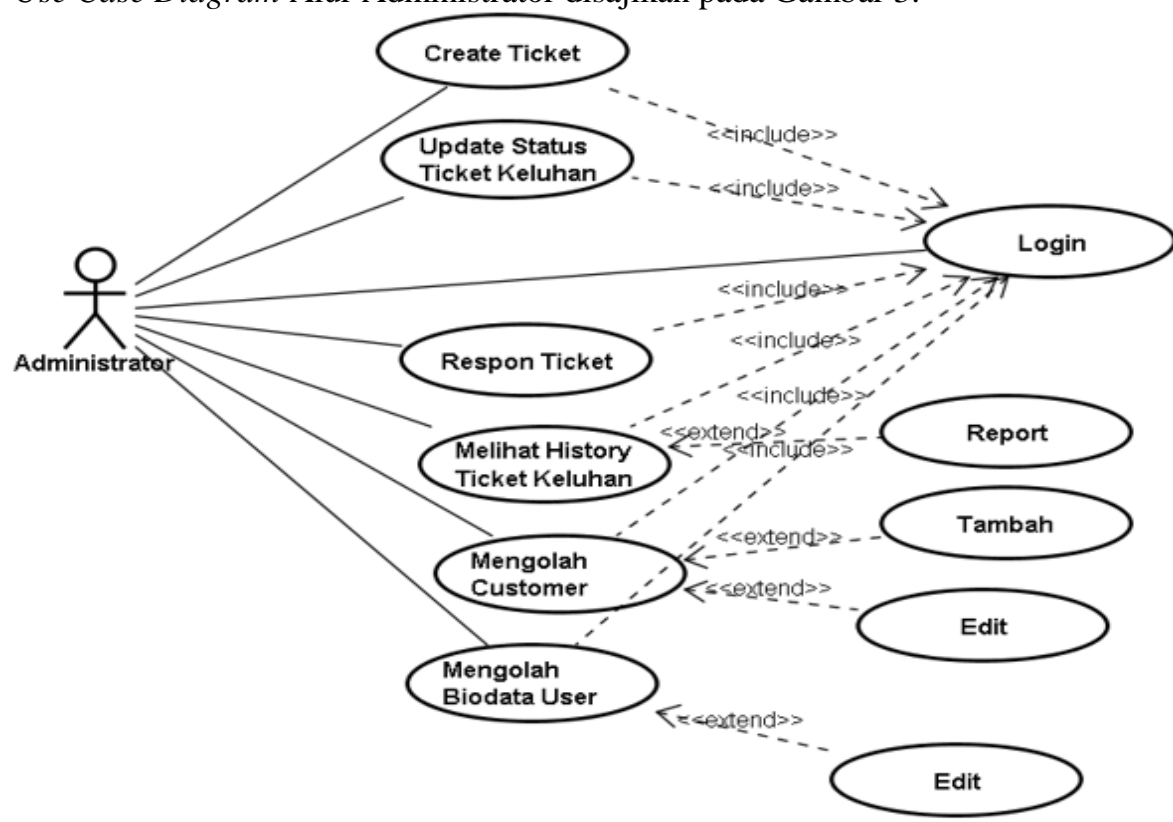

Gambar 3. Use Case Diagram Alur Administrator 
2) Use Case Diagram Alur Administrator

Use Case Diagram alur administrator disajikan pada Tabel 1.

Tabel 1. Use Case Diagram Alur Administrator

\begin{tabular}{ll}
\hline Use Case & Administrator \\
\hline Actor & Administrator \\
\hline Brief Description & $\begin{array}{l}\text { Saat administrator sudah melakukan registrasi dan login } \\
\text { kedalam sistem, maka administrator dapat melakukan beberapa } \\
\text { aktifitas pada sistem informasi adalah sebagai berikut : } \\
\text { 1. Melihat listticket } \\
\text { 2. Membuat } \text { ticket keluhan } \\
\text { 3. Merubah informasi biodata masing - masing administrator, } \\
\text { dan Engineer }\end{array}$ \\
4. Generate Report Ticket Summary berdasarkan tanggal yang \\
telah dibuat customer
\end{tabular}

Sumber: Diolah Penulis

3) Use Case Diagram Alur Engineer

Use Case Diagram Alur Engineer disajikan pada Gambar 4.

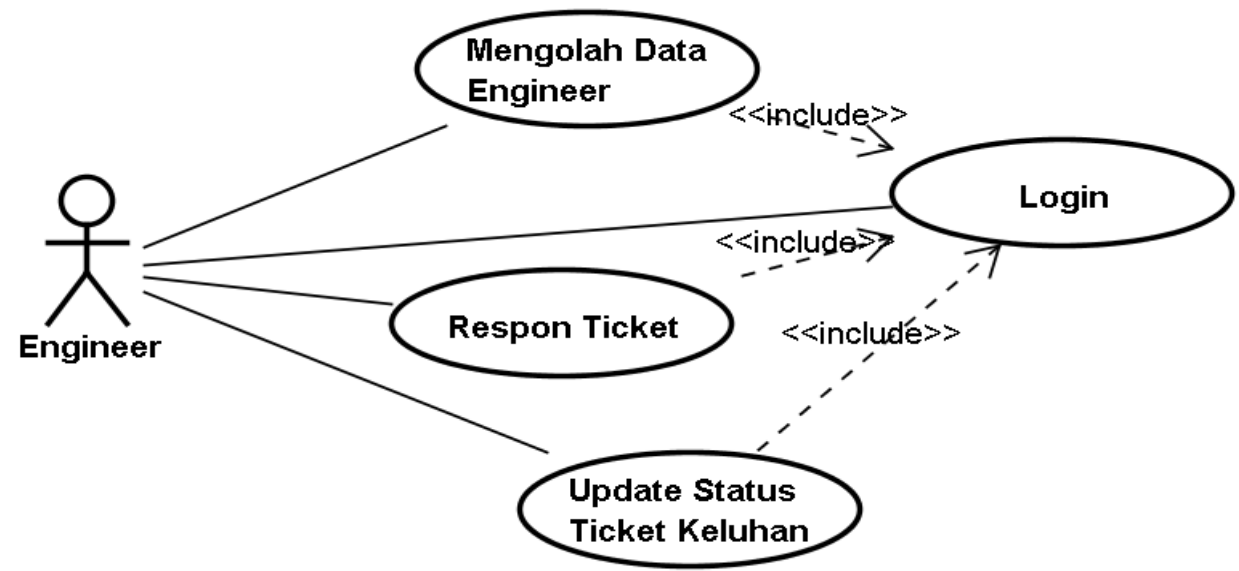

Gambar 4. Use Case Diagram Alur Engineer 
4) Use Case Diagram Alur Customer

Use Case diagram alur customer disajikan pada Tabel 3.

Tabel 3. Use Case Diagram Alur Customer

\begin{tabular}{|l|l|}
\hline Use Case & Customer \\
\hline Actor & Customer/User \\
\hline Brief Description & $\begin{array}{l}\text { Saat Customer sudah melakukan registrasi dan login kedalam } \\
\text { sistem, maka customer dapat melakukan aktifitas sebagai } \\
\text { berikut : } \\
\text { 1. Membuat ticket keluhan baru } \\
\text { 2. Melihat history ticket keluhan yang dibuat masing-masing } \\
\text { costumer yang membuat ticket } \\
\text { 3. Merubah informasi biodata masing - masing customer } \\
\text { 4. Memberikan informasi komentar terhadap penanganan } \\
\text { keluhan } \\
\text { 5. Memberikan feedback rating pada setiap ticket yang } \\
\text { dibuat }\end{array}$ \\
\hline Alternative Flow & $\begin{array}{l}\text { Jika pada saat login, username atau password salah maka } \\
\text { muncul kotak peringatan dan kembali menuju halaman login }\end{array}$ \\
\hline Postcondition & $\begin{array}{l}\text { Jika semua atau sebagian aktifitas telah di lakukan maka } \\
\text { dapat menggunakan fitur logout untuk keluar dari sistem }\end{array}$ \\
\hline Sumber: Diolah Penulis &
\end{tabular}

\section{b. Class Diagram}

Class diagrammerupakan sebuah spesifikasi yang jika diinstansiasi akan menghasilkan sebuah objek dan merupakan inti dari pengembangan dan desain berorientasi objek. Adapun Class Diagram Sistem Informasi Complaint Management disajikan pada Gamabar 6.

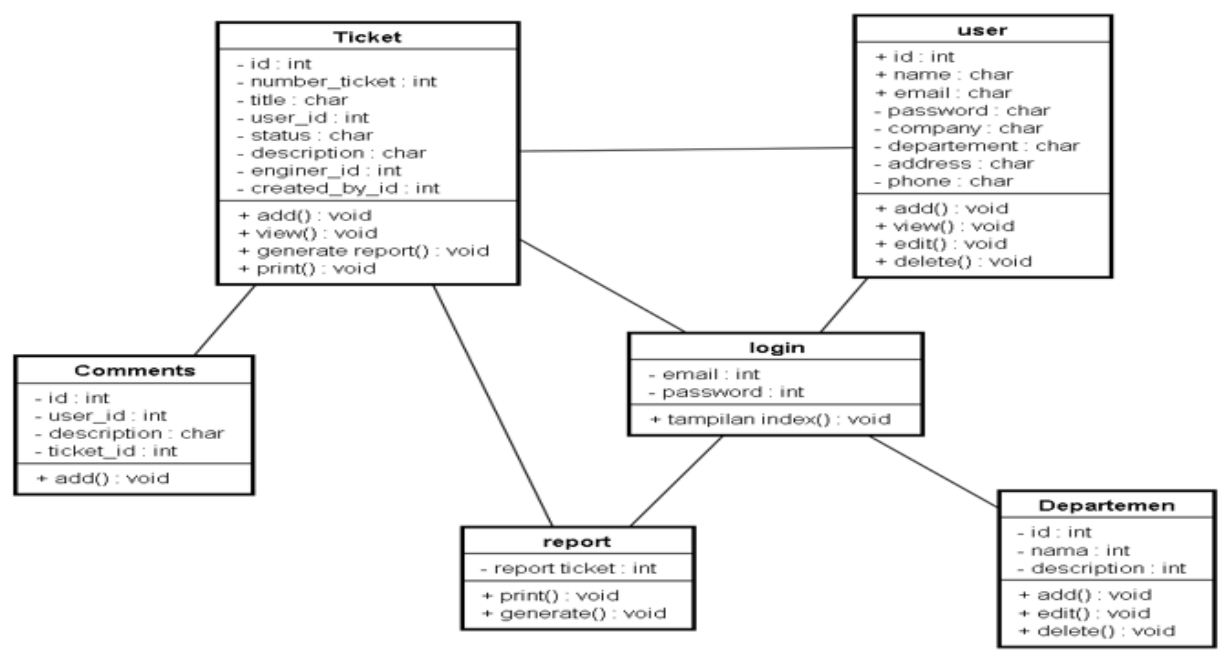

Gambar 6. Class Diagram Sistem Informasi Complaint Management

\section{c. Activity Diagram}

Activity Diagram, memodelkan proses-proses apa saja yang terjadi pada sistem. Berikut Activity Diagram Sistem Informasi Complaint Managementdi PT Andalan Teknologi Mandiri disajikan pada Gambar 7. 


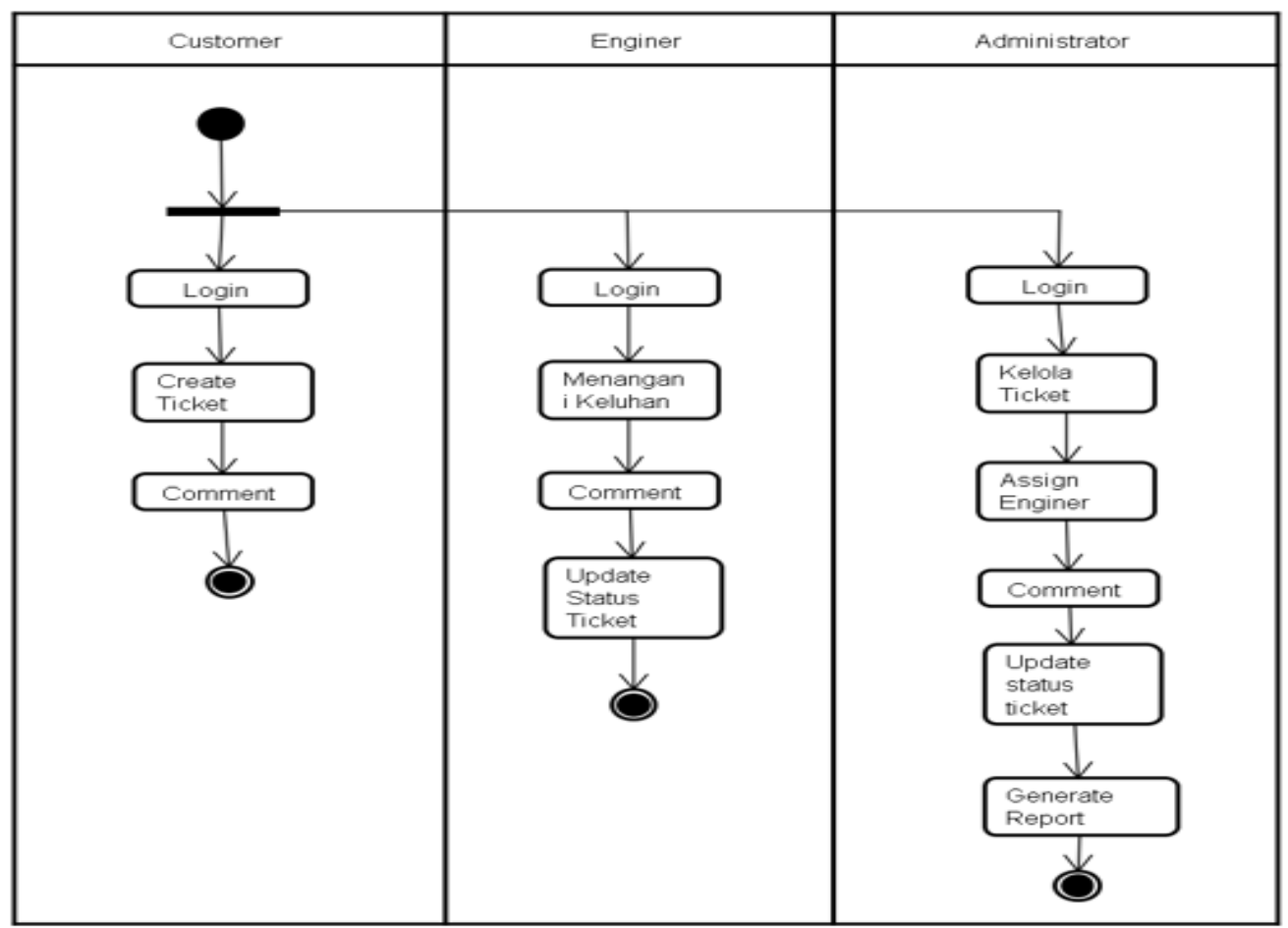

Gambar 7. Activity Diagram Sistem Informasi Complaint Management

\section{d. Statemachine Diagram}

Statemachine Diagram menggambarkan transisi dan perubahan keadaan (dari satu state ke state lainnya suatu objek pada sistem sebagai akibat dari stimuli yang diterima. Statemachine Diagram Sistem Informasi Complaint Management disajikan pada Gambar 8 dan tabel 4.

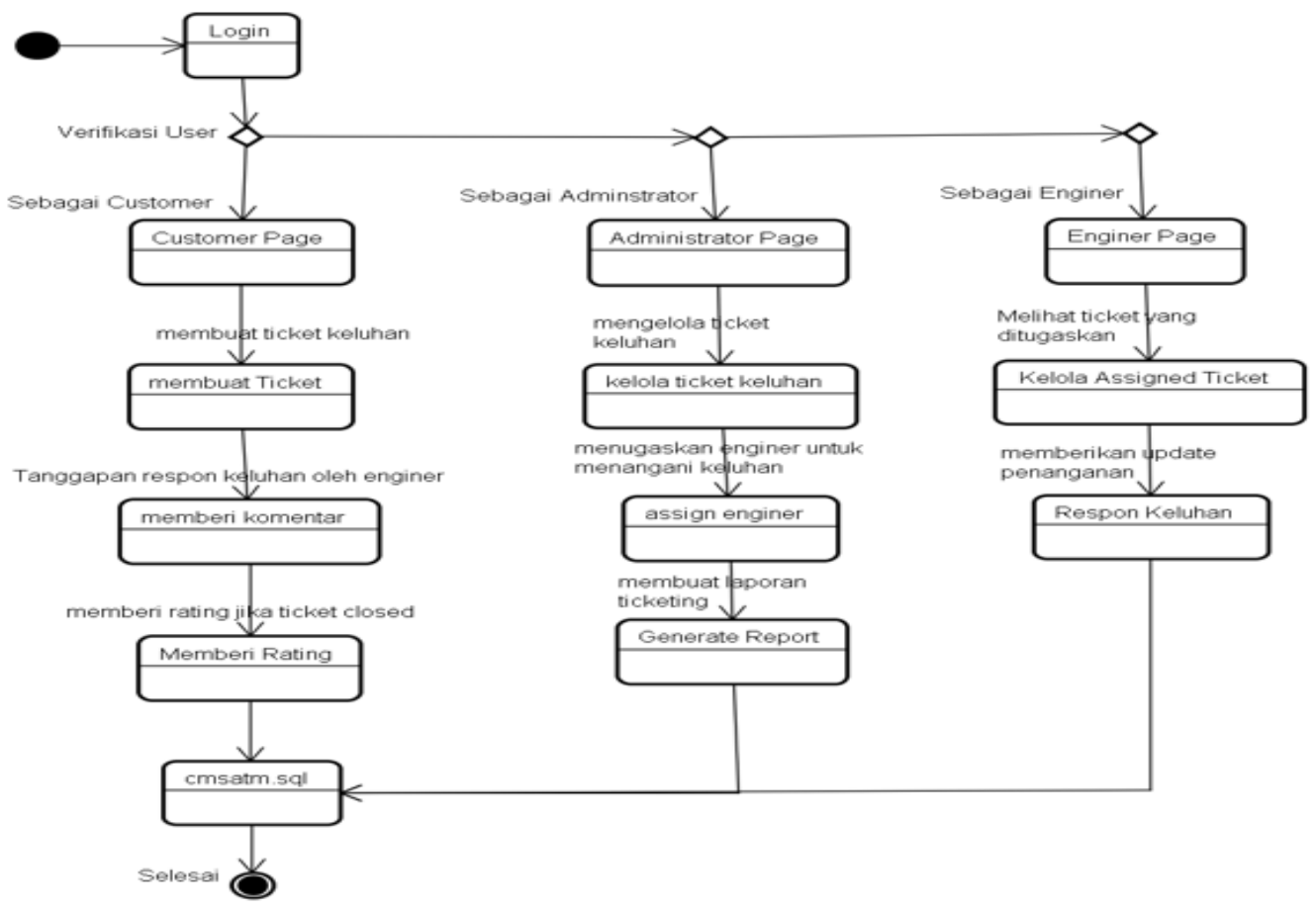

Gambar 8. Statemachine DiagramSistem Informasi Complaint Management 
Tabel 4. Uraian Statemachine Diagram

\begin{tabular}{|c|c|c|}
\hline No & Nama State & Keterangan \\
\hline 1 & Login & $\begin{array}{l}\text { State login memfasilitasi inputan berupa } \\
\text { username dan password untuk masuk pada } \\
\text { sistem informasi complaintmanagement }\end{array}$ \\
\hline 2 & Customer Page & $\begin{array}{l}\text { Halaman customer menampilkan menu ticket, } \\
\text { profile, comment, dan logout. Halaman customer } \\
\text { akan tampil apabila user berhasil login sebagai } \\
\text { customer }\end{array}$ \\
\hline 3 & Engineer Page & $\begin{array}{l}\text { Halaman Engineer menampilkan menu ticket, } \\
\text { profile, comment, dan logout untuk melakukan } \\
\text { respon atas ticket yang dibuat oleh customer. } \\
\text { Halaman Engineer akan muncul apabila user } \\
\text { berhasil login sebagai Engineer }\end{array}$ \\
\hline 4 & Adminstrator & $\begin{array}{l}\text { Halaman administrator menampilkan menu } \\
\text { ticket, user, comment, homepage, dan report. } \\
\text { Menu-menu yang terdapat pada halaman } \\
\text { administrator akan muncul apabila user berhasil } \\
\text { login sebagai admin. }\end{array}$ \\
\hline 5 & Membuat Ticket & $\begin{array}{l}\text { Customer dapat membuat ticket keluhan baru } \\
\text { berdasarkan sub bidang yang di kerjakan } \\
\text { (MechanicalElectrical, InformationTechnology, } \\
\text { CivilWorks). }\end{array}$ \\
\hline 6 & $\begin{array}{l}\text { Memberi } \\
\text { (Customer) }\end{array}$ & $\begin{array}{l}\text { Pada status ini apabila Engineer telah melakukan } \\
\text { penanganan keluhan customer dapat melakukan } \\
\text { komentar pada kolom ticket yang dibuat }\end{array}$ \\
\hline 7 & Memberi Rating (customer) & $\begin{array}{l}\text { Pada status ini apabila ticket berstatus closed, } \\
\text { maka customer berhak untuk menginput rating } \\
\text { feedback terhadap kualitas penanganan keluhan } \\
\text { oleh Engineer berdasarkan masing - masing } \\
\text { ticket yang dibuat }\end{array}$ \\
\hline 8 & $\begin{array}{l}\text { Kelola Ticket } \text { Keluhan } \\
\text { (administrator) }\end{array}$ & $\begin{array}{l}\text { Apabila customer telah membuat ticket maka } \\
\text { administrator melakukan pengolahan berupa } \\
\text { update status ticket sesuai dengan state yang } \\
\text { sedang dikerjaan . (Open, In Progress, Finish, } \\
\text { Close). }\end{array}$ \\
\hline 9 & Assign Ticket (administrator) & $\begin{array}{l}\text { Administrator dapat menentukan Engineer yang } \\
\text { meng-handle ticket keluhan yang dibuat oleh } \\
\text { customer. }\end{array}$ \\
\hline 10 & $\begin{array}{l}\text { Generate } \\
\text { (administrator) }\end{array}$ & $\begin{array}{l}\text { Administrator dapat mengambilan output laporan } \\
\text { daftar ticket menjadi format PDF untuk dicetak } \\
\text { (printout) berdasarkan tanggal dibuatnya ticket }\end{array}$ \\
\hline
\end{tabular}

\section{e. Sequence Diagram}

Sequence Diagram, menjelaskan interaksi objek berdasarkan urutan waktu. Berikut Sequence DiagramSistem Informasi Complaint Management disajikan pada Gambar 9. 


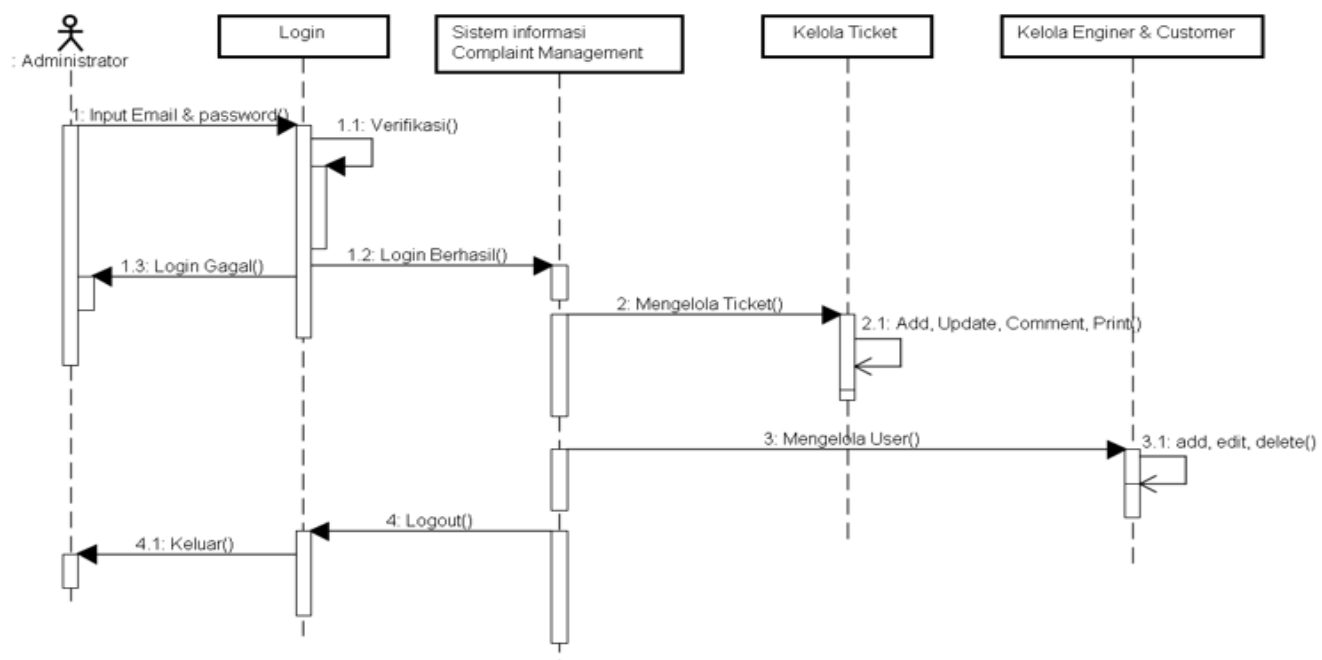

Gambar 9. Sequence Diagram Sistem Informasi Complaint Management

\section{f. Collaboration Diagram}

Collaboration Diagram, menggambarkan interaksi antar objek seperti sequence diagram, tetapi lebih menekankan pada peran masing-masing objek. Collaboration Diagram Sistem Informasi Complaint Management disajikan pada Gambar 10.

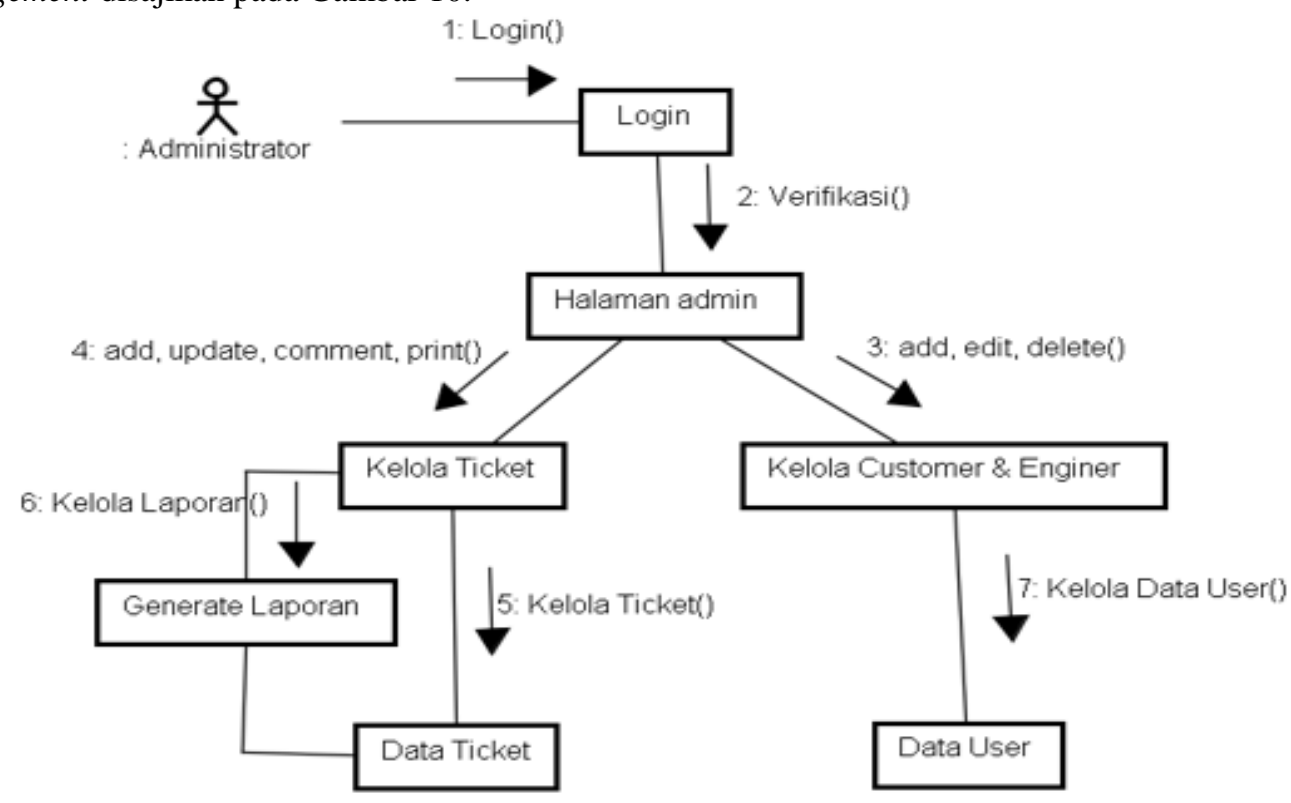

Gambar 10. Collaboration Diagram Sistem Informasi Complaint Management

\section{g. Component Diagram}

Component diagram, menggambarkan struktur dan hubungan antar komponen piranti lunak, termasuk ketergantungan (dependency). Component Diagram Sistem Informasi Complaint Management disajikan pada Gambar 11. 


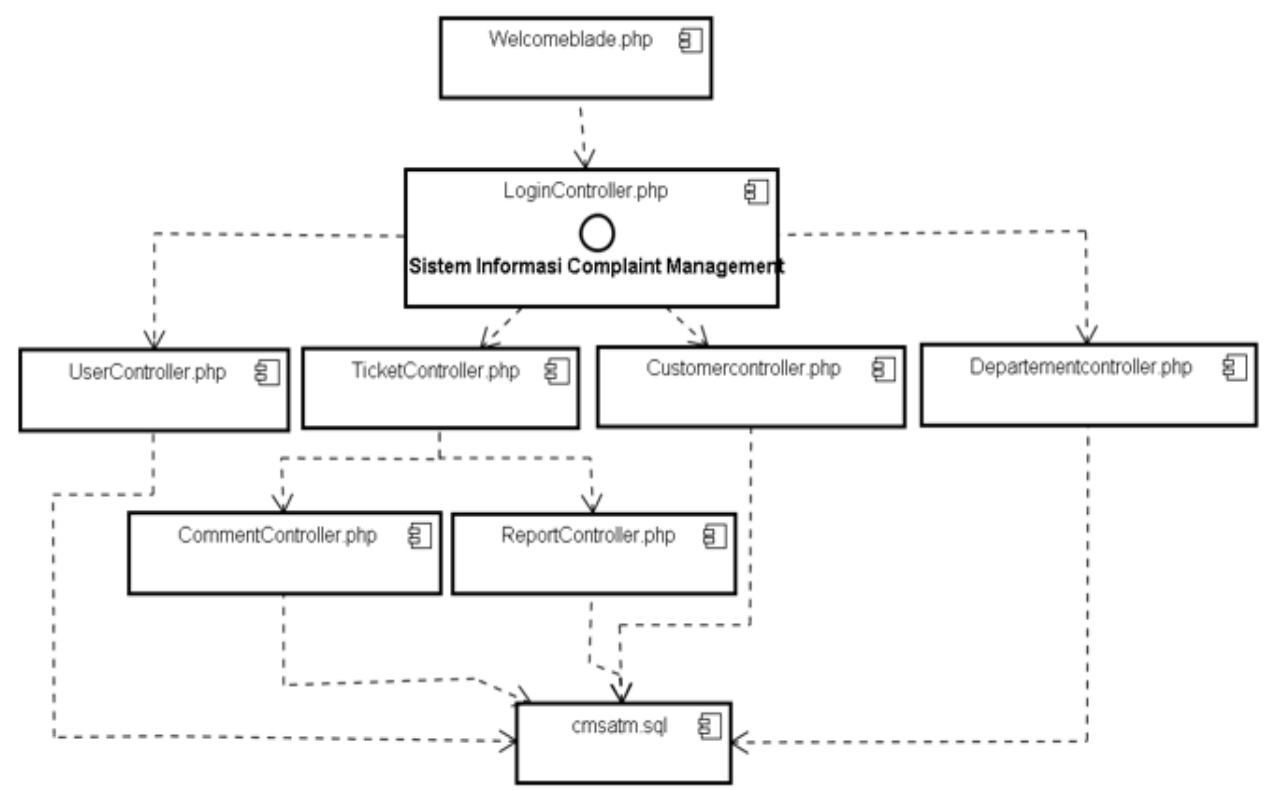

Gambar 11. Component Diagram Sistem Informasi Complaint Management

\section{h. Deployment Diagram}

Deployment diagrammenggambarkan bagaimana komponen di-deploy dalam infrastruktur sistem, di mana komponen akan terletak (pada mesin, server, atau piranti keras apa), bagaimana kemampuan jaringan pada lokasi tersebut, spesifikasi server dan hal-hal lain yang bersifat fisikal. Deployment DiagramSistem Informasi Complaint Management disajikan pada Gambar 12.

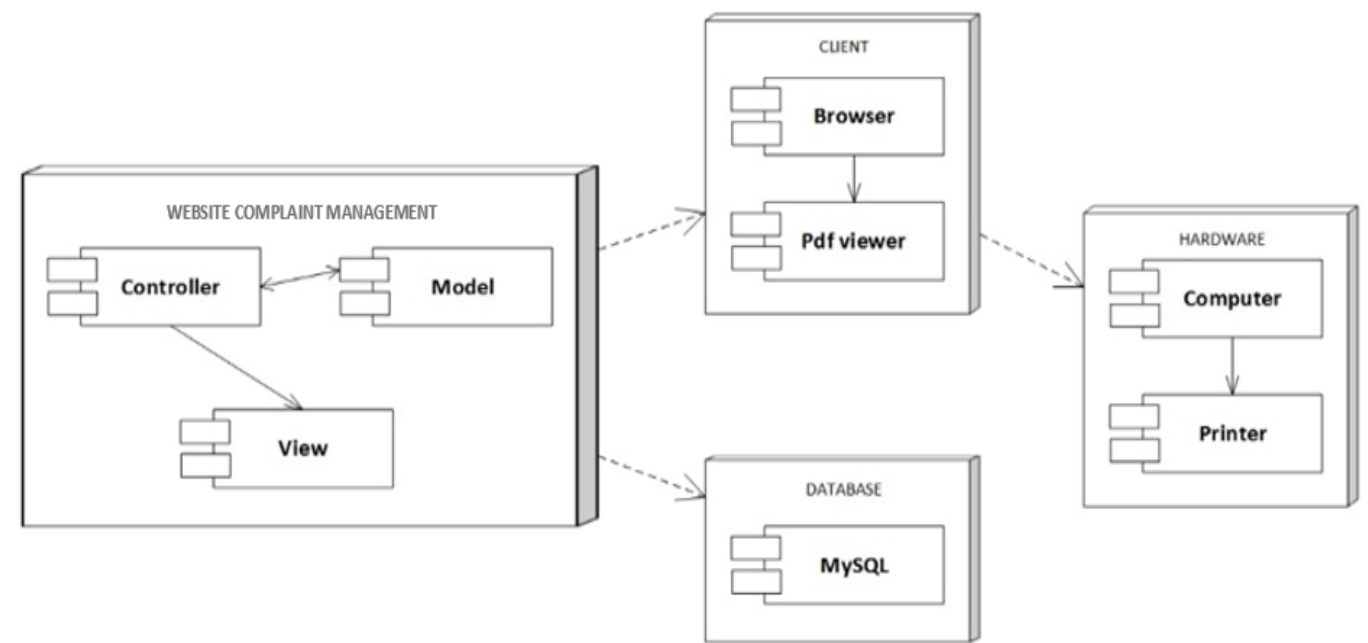

Gambar 12. Deployment Diagram Sistem Informasi Complaint Management 


\subsubsection{Rancangan Dialog Layar}

Rancangan dialog layar disajikan pada Gambar 13.

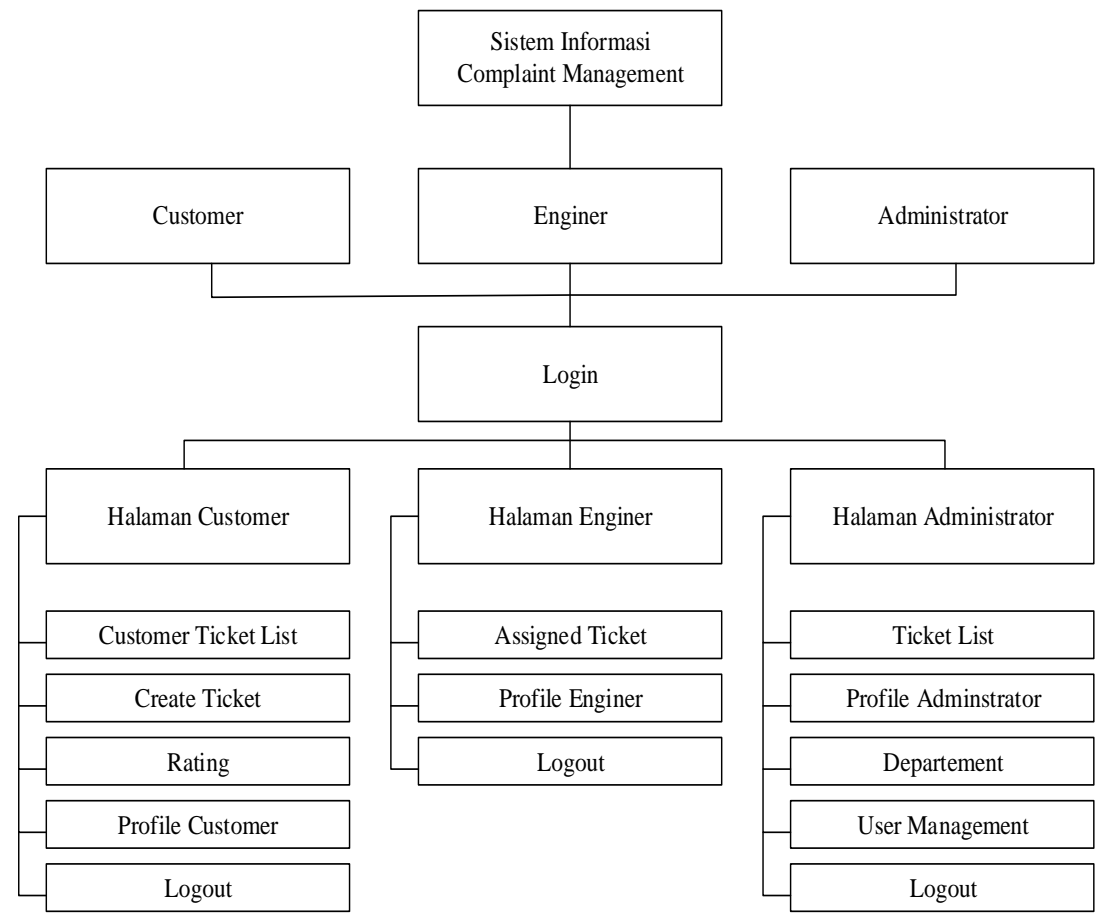

Gambar 13. Rancangan Dialog Layar

\subsubsection{Rancangan Interface}

a. Halaman Welcome Dashboard

Halaman welcome dashboard disajikan pada Gambar 14.
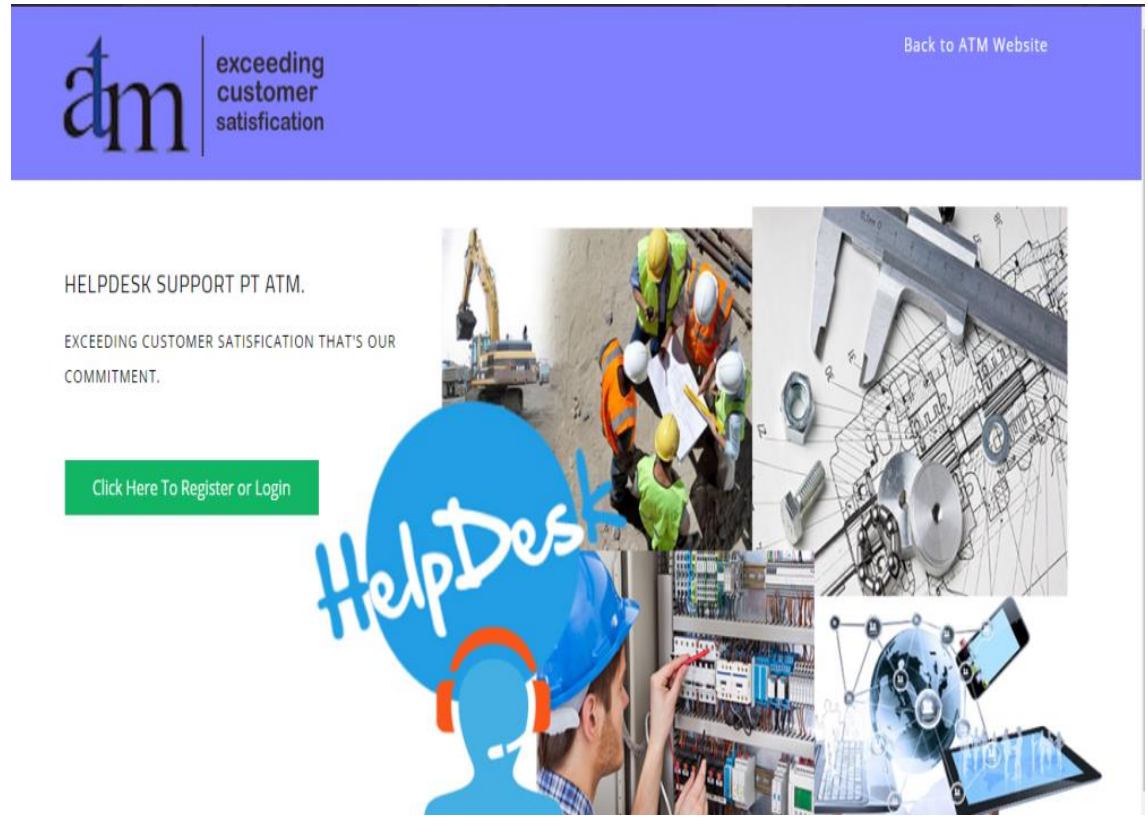

Gambar 14. Tampilan Halaman Welcome Dashboard 


\section{b. Tampilan Halaman Register}

Tampilan halaman register disajikan pada gambar 15.

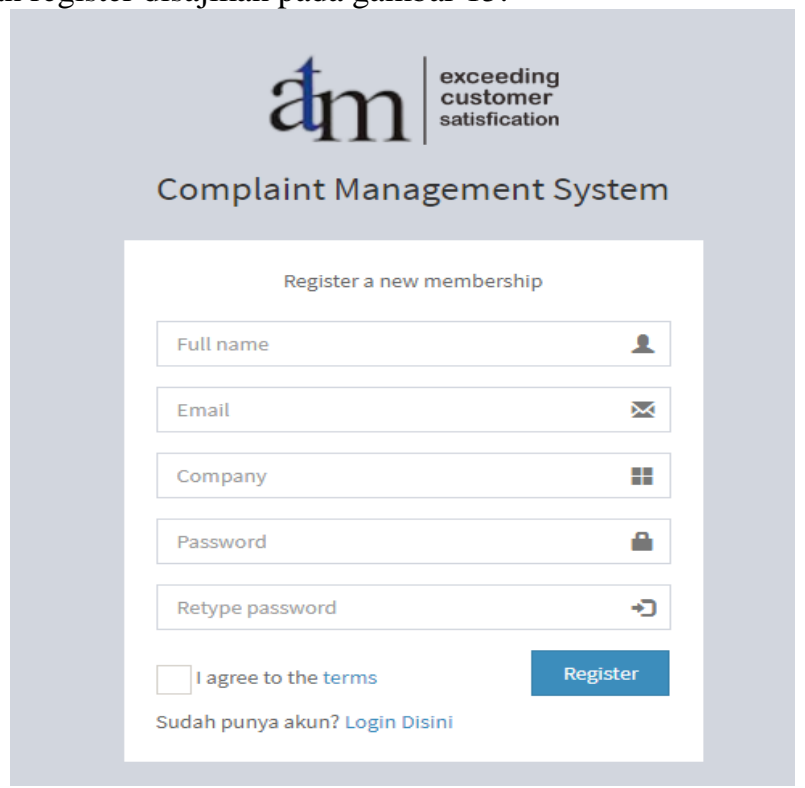

Gambar 15. Tampilan Halaman Register

c. Tampilan Halaman Daftar Tiket Keluhan

Tampilan Halaman Daftar Tiket Keluhan disajikan pada Gambar 16.

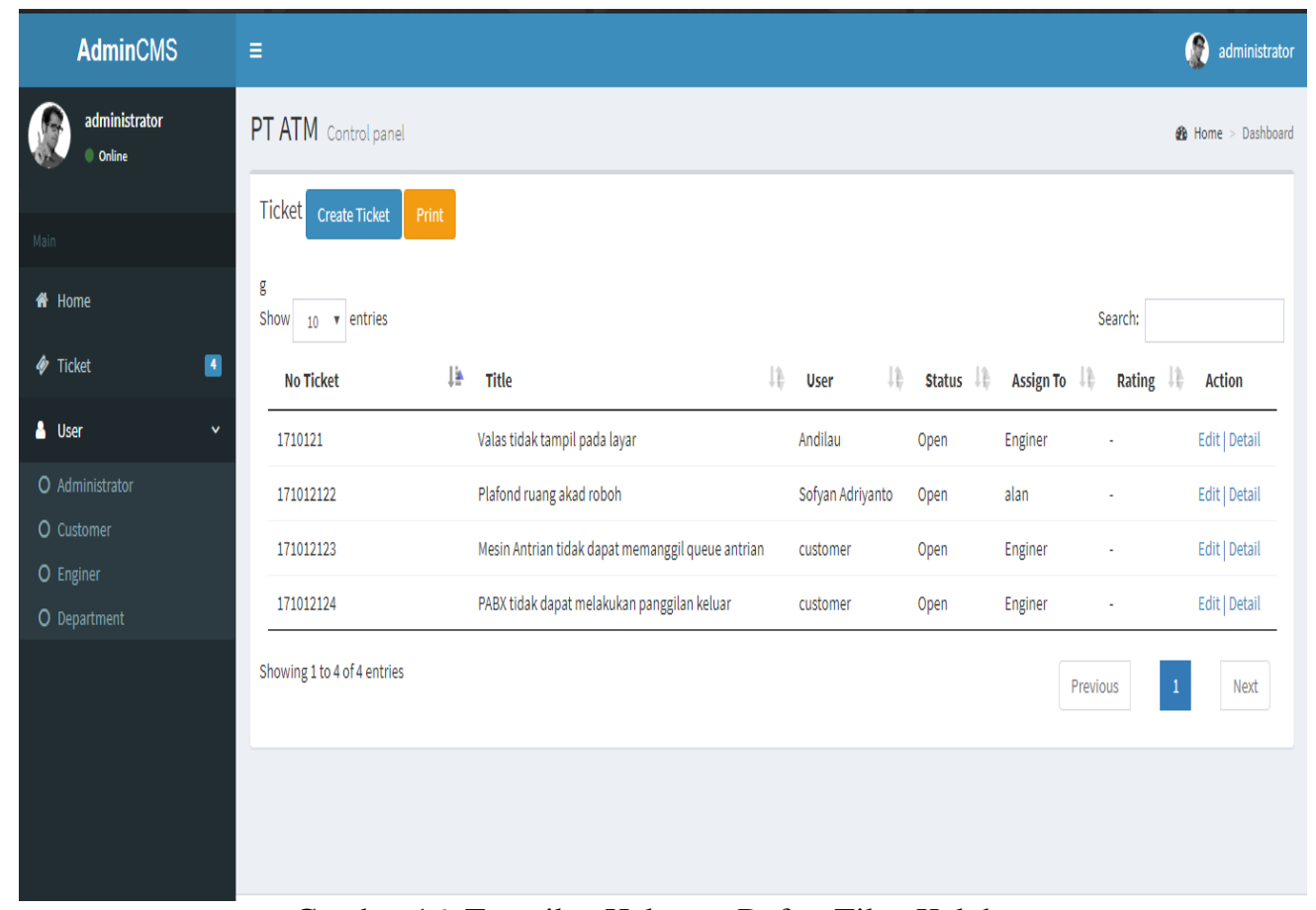

Gambar 16. Tampilan Halaman Daftar Tiket Keluhan 
d. Tampilan Halaman Edit Ticket Keluhan

Tampilan halaman edit ticket keluhan disajikan pada Gambar 17.

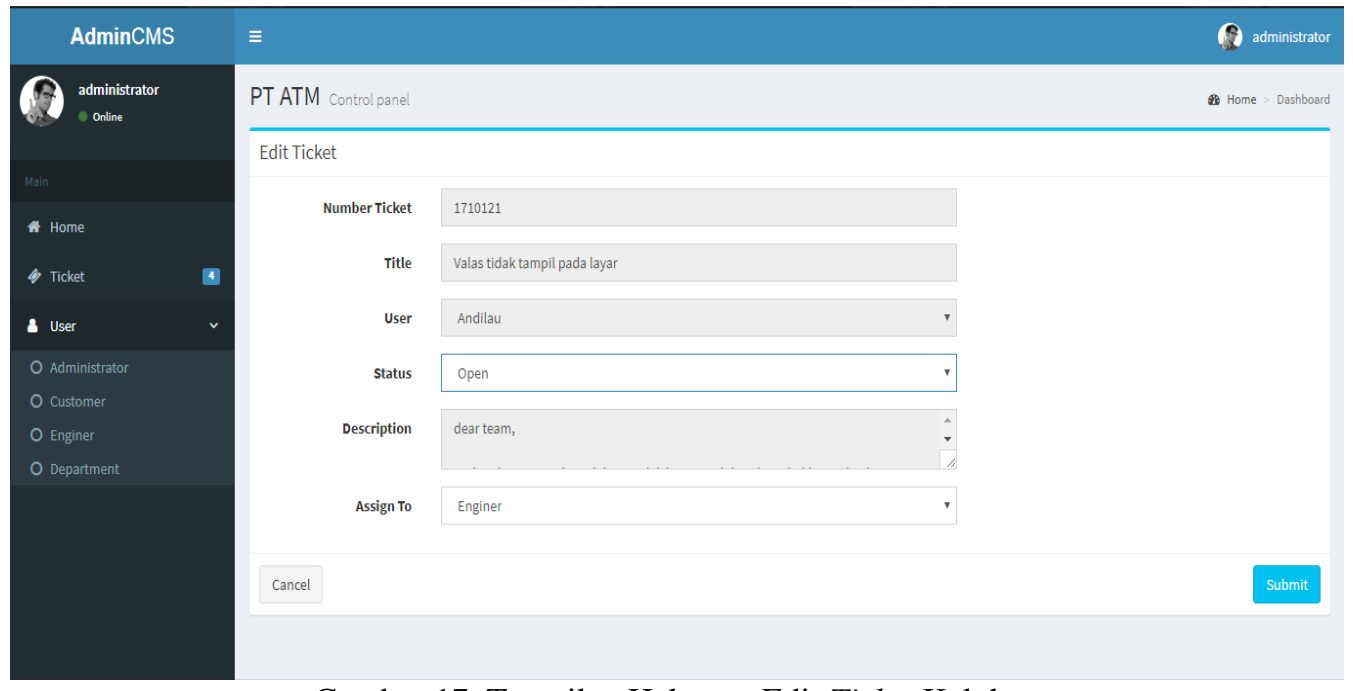

Gambar 17. Tampilan Halaman Edit Ticket Keluhan

e. Tampilan Halaman Detail Ticket Keluhan

Tampilan halaman detail ticket keluhan disajikan pada Gambar 18.

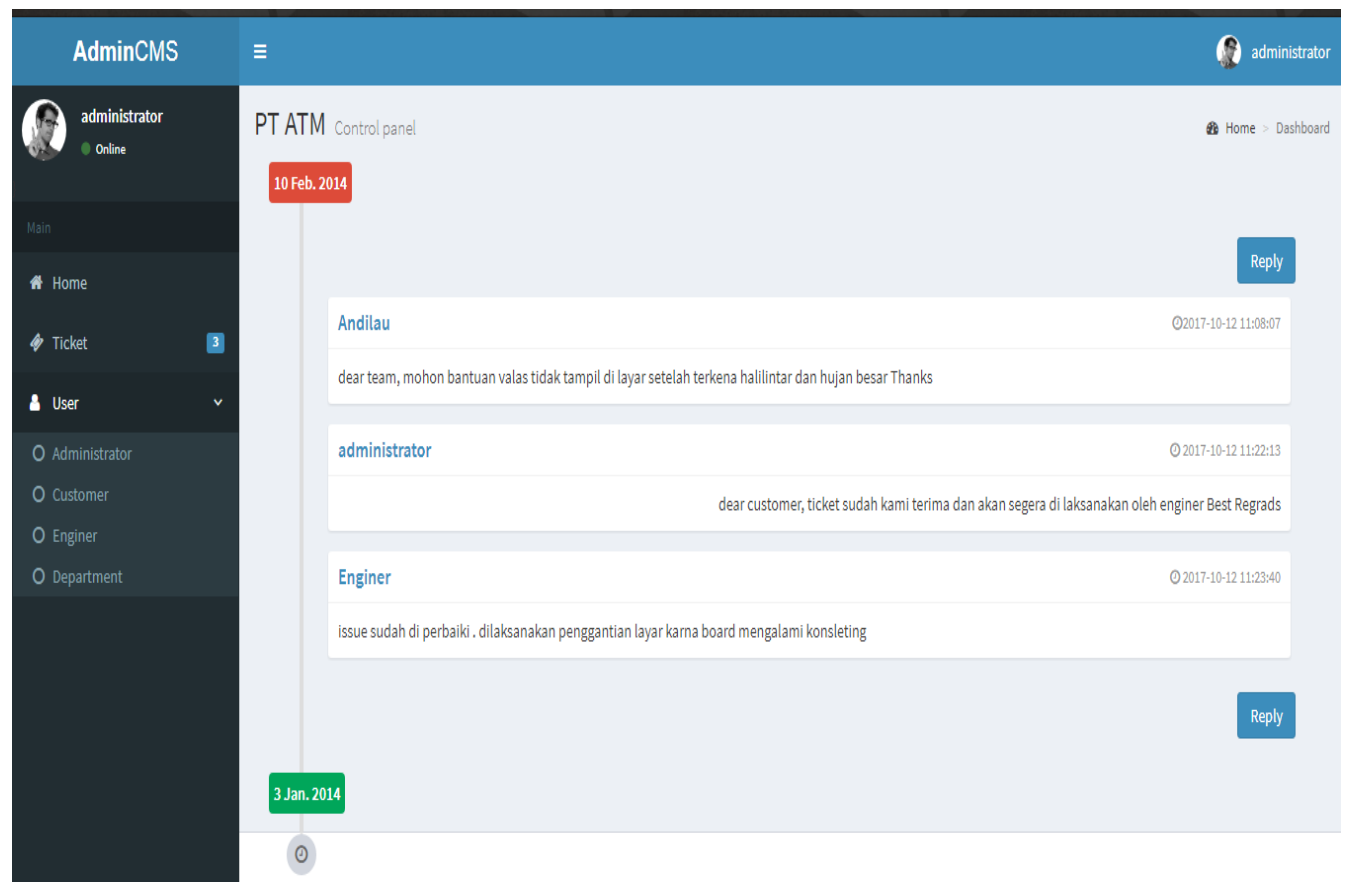

Gambar 18. Tampilan Halaman Detail Ticket Keluhan 


\section{f. Tampilan Halaman Customer}

Tampilan halaman customer disajikan pada Gambar 19.

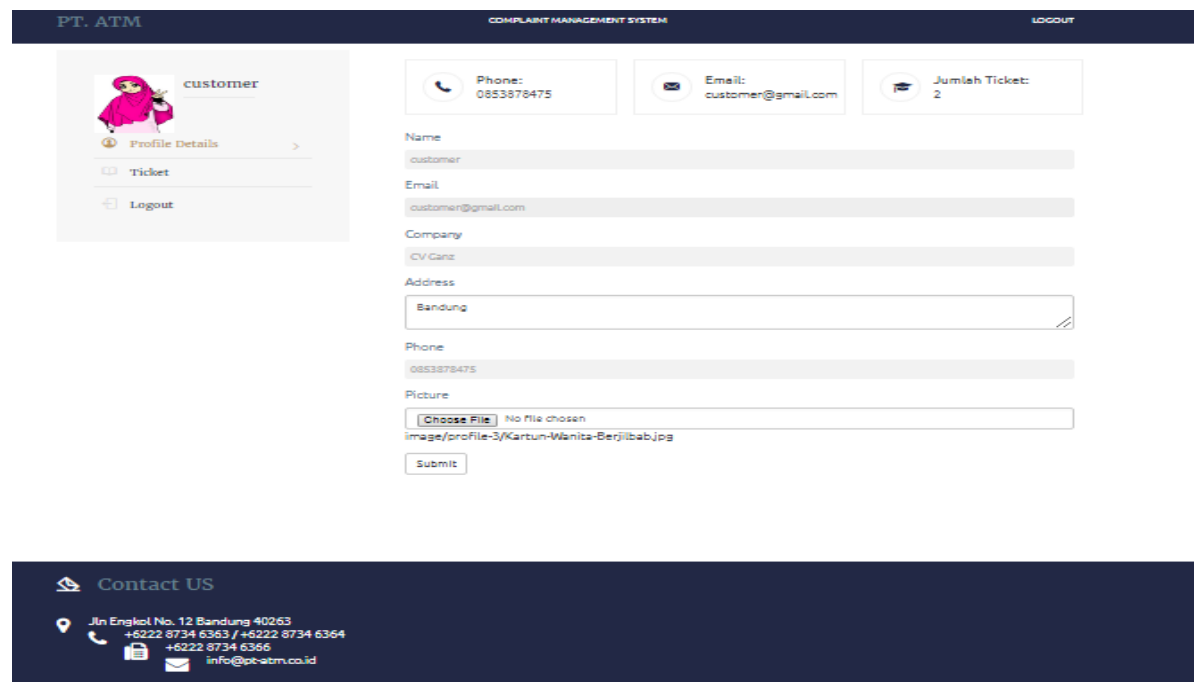

Gambar 19. Tampilan Halaman Customer

\section{KESIMPULAN}

Sistem informasi complaint management yang berjalan di PT Andalan Teknologi Mandiri masih belum terkomputerisasi, sehingga sistem yang berjalan tidak optimal dan belum adanya monitoringkualitas pekerjaan produk dan jasa.Untuk mengatasi permasalahan tersebut perlu dibangun sebuah Sistem Informasi Complaint Management berbasis web yang terintegrasi database agar pengelolaan data lebih cepat, aman dan mudah digunakan

\section{REFERENSI}

1. Hartono, Bambang. 2013. Sistem Informasi Manajemen Berbasis Komputer. Jakarta: Rineka Cipta

2. Nugroho. 2010.Analisis dan Perancangan Sistem Informasi dengan Metodologi Berorientasi Objek, Bandung: Informatika.

3. Pudjo Widodo, Prabowo dan Herlawati. 2011. Menggunakan UML, Bandung: Informatika.

4. Sutabri, Tata. 2012. Analisis Sistem Informasi. Yogyakarta: Andi

5. Sutarman. 2012. Pengantar Sistem Teknologi Informasi. Jakarta: Bumi Aksara

6. Satzinger, Jackson, Burd. 2010. System Analysis And Design With The Unified Process. USA: Course Technology, Cengage Learning.

7. Subhan, Mohamad. 2012. Analisa Perancangan Sistem. Jakarta: Lentera Ilmu Cendekia

8. Yakub. 2012. Pengantar Sistem Informasi. Yogyakarta: Graha Ilmu 